\title{
Edukasi Perilaku Hidup Bersih dan Sehat (PHBS) Pada Masa Pandemi Covid-19 dan Pemberian Sembako Bagi Anak-Anak di Panti Asuhan Al-Hidayah Mataram
}

\author{
Siti Hidayatul Jumaah ${ }^{1}$, Siti Yulianah M. Yusuf ${ }^{2 *}$, Iswan ${ }^{3}$, Johan Mashuri ${ }^{4}$, Vidya Yanti Utami ${ }^{5}$ \\ 1,4,5 Program Studi Ilmu Administrasi Negara, Sekolah Tinggi Ilmu Administrasi Mataram \\ ${ }^{2,3}$ Program Studi Ilmu Administrasi Niaga, Sekolah Tinggi Ilmu Administrasi Mataram \\ 1'hidayatulj929@yahoo.com, 22itiyulianah84@gmail.com, ${ }^{3}$ la.iswan63@gmail.com, \\ ${ }^{4}$ Johan.mashuri@yahoo.com, ${ }^{5}$ vidyautami88@gmail.com
}

\begin{abstract}
Covid-19 has infected many people around the world, even causing death for sufferers. Children are a group that is vulnerable to the spread of Covid-19, especially children who live side by side like in orphanages. This activity aims to educate and assist children at the Al-Hidayah Orphanage in Mataram in implementing Clean and Healthy Living Behavior (PHBS) in order to avoid the transmission of Covid-19. This activity also received high enthusiasm, as seen from the active participation of participants in giving and answering questions. The educational materials for PHBS in preventing COVID-19 were given, namely Clean and Healthy Behavior in Schools, Introduction of COVID-19 and its symptoms, how to wash hands properly and correctly, how to apply cough etiquette, and how to maintain personal hygiene. It can be concluded that this activity succeeded in increasing children's knowledge in implementing clean and healthy living behavior in the school environment, especially in the Al-Hidayah Orphanage Mataram. assistance to those affected by the COVID-19 pandemic.
\end{abstract}

Keywords: Education, Behavior, Clean and Healthy Living, Pandemic, Orphanage Children.

\begin{abstract}
Abstrak
Covid-19 telah menginfeksi banyak orang diseluruh dunia, bahkan menyebabkan kematian bagi penderitanya. Anak-anak merupakan kelompok yang rentan terhadap penyebaran Covid-19, terutama anak-anak yang tinggal di panti asuhan, dimana mereka hidup dengan berdampingan antara satu dengan yang lainnya. Kegiatan ini bertujuan untuk mengedukasi dan mendampingi anak-anak di Panti Asuhan Al-Hidayah Mataram dalam menerapkan protokol kesehatan dalam berperilaku Hidup Bersih dan Sehat (PHBS) agar dapat terhindar dari penularan Covid-19. Kegiatan ini juga mendapat antusias yang tinggi, terlihat dari keaktifan peserta dalam memberi dan menjawab pertanyaan. Adapun materi edukasi PHBS dalam pencegahan Covid-19 yang diberikan yaitu Perilaku Hidup Bersih dan Sehat di Lingkungan Sekolah dan Panti Asuhan, Pengenalan Covid-19 dan gejalanya, menerapkan protokol kesehatan dalam mencuci tangan dengan baik dan benar, cara menerapkan etika batuk, serta cara menjaga kebersihan diri dalam kehidupan sehari-hari. Kegiatan ini dapat disimpulkan berhasil meningkatkan pengetahuan anak-anak dalam menerapkan perilaku hidup bersih dan sehat di lingkungan sekolah, terutama di lingkungan Panti Asuhan Al-Hidayah Mataram. Kegiatan edukasi ini juga dibarengi dengan kegiatan pembagian sembako kepada anak-anak di Panti Asuhan sebagai upaya memberikan bantuan kepada mereka untuk memenuhi kebutuhan hidup sehari-hari.
\end{abstract}

Kata Kunci: Sosialisasi, Perilaku, Hidup Bersih dan Sehat, Pandemi Covid-19, Penghuni Panti Asuhan. 


\section{PENDAHULUAN}

Corona Virus Disease atau yang lebih dikenal dengan istilah Covid-19 merupakan jenis penyakit baru yang muncul sejak akhir tahun 2019. Penyakit ini disebabkan oleh infeksi virus Respiratory Syndrome Coronavirus 2 (SARS-COV2) yang dapat menyebabkan gangguan sistem pernapasan, mulai dari gejala ringan seperti flu, hingga infeksi paru-paru, seperti pneumonia. Bahkan, penyakit ini dapat menyebabkan kematian. Hingga September 2021, Covid-19 telah menginfeksi 223.022.538 orang dan menyebabkan kematian terhadap 4.602.882 orang di seluruh dunia (WHO, 2021). Sementara di Indonesia, jumlah kasus yang terkonfirmasi sebanyak 4.158 .731 orang, dimana 138.431 orang diantaranya meninggal dunia (Covid-19, 2021).

Singlah (2020) menyebutkan bahwa Covid-19 ditularkan melalui droplet (percikan) pada saat orang yang sedang terinfeksi berbicara, batuk, dan bersin. Sementara pendapat WHO (2020), penyebaran Covid-19 dapat melalui; droplet (saat seseorang batuk, bersin, bernyanyi, berbicara hingga bernafas), melalui udara (partikel-partikel kecil yang melayang diudara), melalui permukaan yang terkontaminasi, melalui fecal-oral atau limbah manusia (urine dan feses), serta bias melalui darah, dari ibu ke anak hingga dari hewan ke manusia. Huang dkk (2020) menyebutkan bahwa gejala yang daoat muncuk akibat virus Covid-19 ini mulai dari gejala flu biasa hingga komplikasi berat. Flu biasa, misalnya demam, pilek, batuk, nyeri otot, nyeri tenggorokan, dan nyeri kepala, Sedangkan komplikasi berat berupa pneumonia, diare, hingga meninggal dunia.

Virus Covid-19 tidak hanya menyerang orang dewasa, tetapi juga anak-anak. Meskipun anak-anak memiliki resiko yang lebih kecil untuk mengalami gejala Covid-19 yang bertahan lama seperti orang dewasa, namun data Satgas penanganan Covid-19 mengungkapkan secara kumulatif hingga per 16 Juli 2021, ada 777 anak di Indonesia yang meninggal akibat Covid-19. Persentase angka kematian tertinggi (CFR) berada pada kelompok usia 0-2 tahun, diikuti kelompok usia 16-18 tahun dan 3-6 tahun. Gejala awal pada anakanak umumnya akan merasakan sakit kepala, kelelahan, sakit tenggorokan, dan gangguan penciuman atau anosmia. Gejala yang muncul tergantung dari lamanya durasi anak-anak terinfeksi virus. (herminahospitals.com, reviewed by dr. Yeni Halim, M. Ked (Ped) Sp.A).

Tingginya angka penularan Covid-19 bagi anakanak sesuai data di atas perlu menjadi perhatian bersama. Salah satu langkah untuk meminimalisir hal tersebut adalah dengan membekali anak-anak pengetahuan mengenai Perilaku Hidup Bersih dan Sehat (PHBS). Hal ini ditujukan agar anak-anak dapat menerapkan perilaku hidup bersih dan sehat di lingkungan manapun mereka berada, termasuk di lingkungan sekolah maupun tempat tinggal mereka.

Pengetahuan mengenai PHBS (Perilaku Hidup Bersih dan Sehat) sangat diperlukan terutama pada anakanak yang tinggal di Panti Asuhan. Panti Asuhan AlHidayah merupakan salah satu panti asuhan yang terletak di Batu Ringgit Kelurahan Tanjung Karang, Kota Mataram. Berdasarkan hasil observasi, terdapat 55 orang penghuni panti yang merupakan anak usia sekolah dari tingkat sekolah dasar hingga sekolah menengah keatas. Anak-anak tersebut berasal dari kelompok yatim/piatu/yatim piatu dan anak-anak dari keluarga tidak mampu.

Hasil wawancara antara tim abdimas dengan ketua pengasuh panti asuhan diperoleh informasi bahwa selama masa pandemi Covid-19, anak-anak sangat membutuhkan edukasi mengenai penerapan protokol kesehatan, perilaku hidup bersih dan sehat, serta uluran bantuan dalam pemenuhan kebutuhan hidup sehari-hari. Pengasuh panti asuhan lebih lanjut menerangkan sulitnya penerapan protokol kesehatan bagi anak-anak terutama mengenai penggunaan masker, kebiasaan mencuci tangan, dan menjaga jarak. Hal ini disebabkan oleh mayoritas anakanak di panti asuhan Al-Hidayah masih dalam usia bermain, sehingga penerapan protokol kesehatan tersebut dapat menggangu aktivitas bermain mereka.

Selain itu, hasil wawancara bersama pihak panti asuhan juga menunjukkan minimnya pengetahuan anakanak mengenai perilaku hidup bersih dan sehat. Menurut informan, anak-anak masih memiliki kesadaran yang rendah mengenai cara menjaga kesehatan, baik untuk diri mereka sendiri maupun untuk lingkungan sekitar. Anakanak juga terlihat jarang mencuci tangan baik sebelum maupun sesudah melakukan aktivitas, padahal pihak 
panti asuhan sudah seringkali memberikan himbauan untuk mencuci tangan. Pengetahuan mengenai etika batuk dan bersin menurut pihak panti asuhan juga perlu dilakukan, mengingat anak-anak asuhan mereka masih memiliki pengetahuan yang rendah akan hal tersebut.

Selain permasalahan di atas, adanya pembatasan sosial (social distancing) di masa pandemi covid-19 saat ini juga berdampak terhadap berkurangnya bantuan donatur dalam pemenuhan kebutuhan sehari-hari anakanak di Panti Asuhan Al-Hidayah Mataram. Sebagaimana diketahui bahwa panti asuhan menggantungkan pemenuhan kebutuhan pokok mereka dari sumbangan dan bantuan dari donatur.

Dalam rangka mengatasi berbagai permasalahan penerapan protokol kesehatan di Panti Asuhan AlHidayah Mataram, maka tim abdimas memberikan solusi, yakni melakukan kegiatan edukasi Perilaku Hidup Bersih dan Sehat (PHBS) sesuai protokol kesehatan di masa pandemi covid-19. Adapun kegiatan edukasi tersebut terdiri dari: 1) memberikan pemahaman mengenai cara mencuci tangan yang baik dan benar, 2) cara menerapkan etika batuk, 3) cara melakukan physical distancing (menjaga jarak fisik), dan 4) cara menjaga kebersihan diri dan lingkungan sekitar.

Edukasi ini dapat diberikan melalui penyuluhan atau dengan menggunakan media berupa poster, dimana poster merupakan salah satu bentuk media pembelajaran cetak yang dapat dengan mudah digunakan untuk menyampaikan informasi kepada pembaca (Razi dkk, 2020; Arsyad, 2013). Selain edukasi perilaku hidup bersih dan sehat, panti asuhan juga perlu diberikan bantuan berupa sembako sebagai bentuk pemenuhan kebutuhan hidup sehari-hari.

Berdasarkan paparan situasi di atas, maka kegiatan pengabdian kepada masyarakat dilakukan dengan melaksanakan kegiatan edukasi pentingnya menerapkan pola hidup bersih dan sehat dalam bentuk penyuluhan, pemberian poster, dan pemberian bahan-bahan lain yang dapat digunakan untuk mencegah penularan Covid-19. Dengan edukasi tersebut, diharapkan anak-anak penghuni panti asuhan yang hidup secara berdampingan sehari-hari dapat memahami dan menerapkan protokol kesehatan berupa pola hidup bersih dan sehat dalam kehidupan mereka sehari-hari. Selain itu, kegiatan pengabdian ini juga dibarengi dengan pemberian sembako berupa beras, minyak goreng, gula pasir, susu, dan lain-lain dengan tujuan untuk membantu pemenuhan kebutuhan hidup penghuni panti asuhan terutama selama masa pandemi Covid-19 ini.

\section{METODE}

Kegiatan ini dilaksanakaan pada hari Minggu, 17 Agustus 2021 yang melibatkan partisipasi dari 55 orang anak-anak di Panti Asuhan Al-Hidayah Mataram. Adapun tahapan dalam pelaksanaan kegiatan ini terbagi menjadi tiga, yaitu: tahap perencanaan, tahap implementasi, dan tahap penilaian.

Pertama, tahap perencanaan merupakan tahap mengidentifkasi berbagai problem yang ada di Panti Asuhan Al-Hidayah Mataram. Identifikasi masalah ini dilakukan melalui dua teknik, yaitu wawancara kepada pihak panti asuhan, dan observasi terhadap lingkungan panti asuhan. Selain itu, tahap persiapan ini juga meliputi penyiapan materi edukasi yang akan disampaikan, penyiapan media edukasi baik berupa poster maupun $\mathrm{x}$ banner, dan penyiapan sembako yang akan dibagikan.

Kedua, tahap implementasi kegiatan dilakukan dengan memberikan penyuluhan mengenai perilaku hidup bersih dan sehat sesuai protokol kesehatan. Edukasi ini dilakukan melalui ceramah, pendampingan, dan bimbingan mengenai PHBS dalam mencegah tersebarnya Covid-19 bagi anak-anak. Penyampaian materi ini dilakukan dengan beberapa metode, yaitu metode ceramah, tanya jawab, diskusi, dan demonstrasi. Sementara itu, untuk pemberian sembako, dilakukan dengan cara serah terima secara simbolis oleh pihak fasilitator dengan pihak Panti Asuhan Al-Hidayah Mataram.

Ketiga, tahap penilaian meliputi evaluasi pengetahuan anak-anak sebagai peserta kegiatan. Tahap penilaian ini dilakukan pada saat sebelum dan sesudah anak-anak mendapat pengetahuan mengenai PHBS. Evaluasi sebelum kegiatan dilakukan dengan tujuan untuk mengetahui sejauh mana pengetahuan peserta tentang perilaku hidup bersih dan sehat, sementara evaluasi setelah kegiatan dilakukan dengan tujuan untuk mengetahui pengaruh dan keberhasilan dari kegiatan edukasi yang telah dilakukan. Metode evaluasi sebelum 
kegiatan dilakukan melalui tanya jawab terhadap anakanak dan pengelola panti asuhan. Pertanyaan yang disampaikan berisi tentang pengetahuan peserta mengenai perilaku hidup bersih dan sehat dalam pencegahan Covid-19. Sementara metode evaluasi setelah kegiatan dilakukan melalui refleksi bersama tim pengabdian terkait hasil kegiatan edukasi yang telah dilakukan, juga membuat hasil laporan pengabdian.

\section{HASIL DAN PEMBAHASAN}

Pelaksanaan kegiatan edukasi perilaku hidup bersih dan sehat (PHBS) dalam pencegahan COVID-19 di Panti Asuhan Al-Hidayah Kota Mataram, telah terlaksana dengan baik mulai dari tahap persiapan hingga tahap evaluasi. Adapun hasil kegiatan dapat dilihat pada paparan di bawah ini:

\section{Tahap Perencanaan}

a. Penentuan Lokasi Pengabdian

Lokasi pengabdian dalam abdimas ini ditentukan berdasarkan pada, yaitu: 1) kebutuhan panti asuhan untuk memperoleh penyuluhan mengenai PHBS, dimana panti asuhan tersebut belum sama sekali memperoleh edukasi mengenai PHBS selama Covid-19, 2) panti asuhan tersebut didiami oleh anak-anak usia sekolah, baik dari tingkat sekolah dasar hingga menengah ke atas. 3) pengelola dari panti asuhan memiliki kemauan untuk bekerjasama, dimana mereka memberikan izin untuk tim abdimas melakukan edukasi mengenai PHBS, 4) lokasi panti asuhan masih dalam lingkup Kota Mataram, sehingga masih bisa dijangkau oleh tim.

b. Penentuan Materi Edukasi

Materi edukasi PHBS ditentukan melalui diskusi bersama tim. Adapun materi yang dipilih terdiri dari etika batuk dan bersin, serta cara mencuci tangan yang baik dan benar. Materi-materi tersebut dianggap sangat penting dan memiliki pengaruh besar pada kebiasaan anak-anak untuk berprilaku hidup bersih dan sehat pada setiap aktivitasnya Kebiasaan ini selanjutnya dapat meminimalisir resiko penularan Covid-19 bagi anakanak.

c. Penengtuan Sarana dan Prasarana Pengabdian

Sarana dan prasarana yang perlukan dalam mendukung edukasi perilaku hidup bersih dan sehat selama pandemi Covid-19 berupa banner dalam bentuk gambar. Selain itu, alat yang mendukung kegiatan edukasi pencegahan Covid-19 seperti: masker, sabun, dan handsanitizer. Untuk pembagaian semabko, tim mendiskusikan beberapa sembako yang dipilih sesuai dengan kebutuhan panti asuhan, diantaranya: beras, telur, mie instan, minyak goreng, susu, dan lain sebagainya.

\section{Tahap Implementasi}

a. Edukasi Perilaku Hidup Bersih dan Sehat selama Pandemi Covid-19

Edukasi ini dilakukan melalui beberapa cara, yaitu: pertama, dengan memberikan pengatuhan mengenai PHBS kepada anak-anak melalui metode cermah. Kedua, melakukan pendampingan dan bimbingan kepada anakanak terkait etika bersin dan batuk, cara mencuci tangan yang baik dan benar, hingga cara menjaga kebersihan diri dan lingkungan. Kegiatan edukasi perilaku hidup bersih dan sehat di Panti Asuhan Al-Hidayah Mataram dapat dilihat pada gambar di bawah ini:

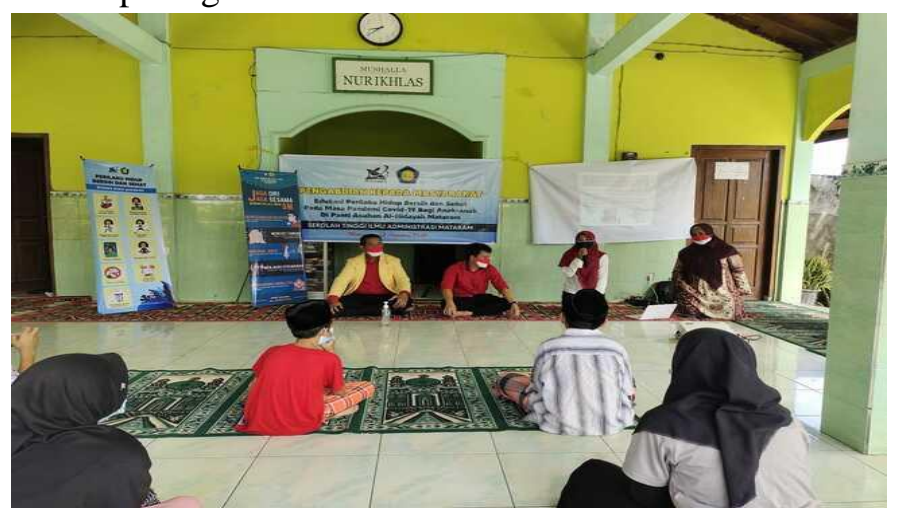

Gambar 1. Kegiatan Edukasi Perilaku Hidup Bersih dan Sehat

Kegiatan ini diikuti oleh peserta dengan antusias dan motivasi yang tinggi untuk belajar. Hal ini dilihat dari kehadiran peserta sejak dimulainya acara hingga berakhirnya acara, juga keaktifan peserta dalam hal bertanya maupun menjawab pertanyaan-pertanyaan yang diberikan oleh fasilitator. Fasilitator dalam pengabdian ini terdiri dari tim pengabdian yang merupakan dosen, dan mahasiswa. Antusias dan keaktifan peserta mengikuti edukasi pola hidup bersih dan sehat lebih lanjut dapat dilihat pada gambar di bawah ini: 


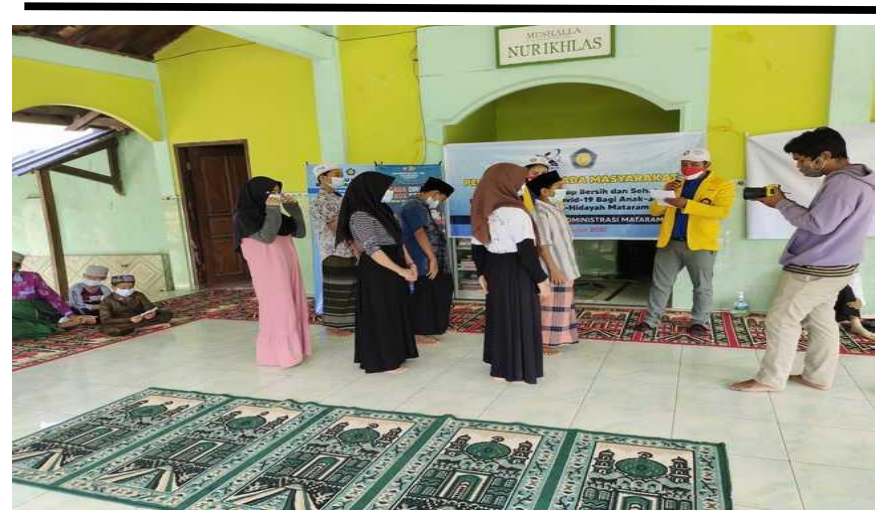

Gambar 2. Antusias Peserta dalam Edukasi Perilaku Hidup Bersih dan Sehat

Media yang digunakan dalam edukasi ini adalah xbanner. Media x-banner yang dipilih adalah x-banner yang di dalamnya terdapat gambar berupa ilustrasi mengenai Perilaku Hidup Bersih dan Sehat (PHBS) dan Protokol Kesehatan dan mencegah Covid-19. X-banner ini selanjutnya diletakkan kelas dan musholla agar anakanak selalu melihat dan pada akhirnya dapat mengingat cara- cara menerapkan PHBS di lingkungan sekolah sehingga terhindar dari penularan COVID-19.

Kamus Besar Bahasa Indonesia (KBBI), mendefinisikan banner sebagai suatu pesan atau berita yang dijadikan informasi bagi khalayak ramai dan menjadi bahasa promosi untuk berdagang yang menarik minat konsumen untuk mengenali produk yang di iklankan.

Hal ini sesuai dengan pendapat Darmadi Durianto (2011) yang mengatakan bahwa banner merupakan suatu proses komunikasi yang memiliki tujuan untuk membujuk banyak orang untuk membeli dan menggunakan apa yang diiklankan dan menjadi sebuah promosi yang dapat meningkatkan ingatan dan daya beli orang-orang akan sebuah produk.

Edukasi menggunakan $\mathrm{x}$-banner dapat dilihat pada Gambar 3 di bawah ini:

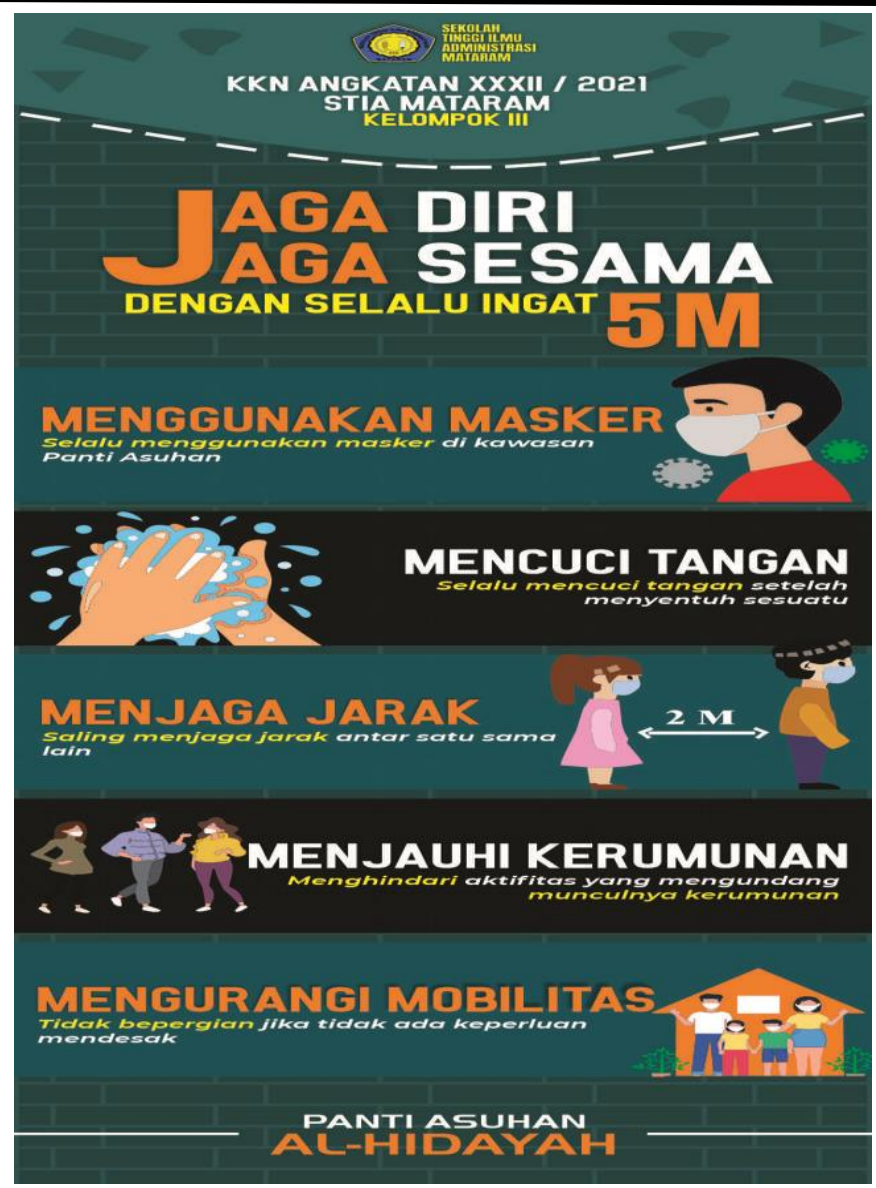

Gambar 3. X-Banner Protokol Kesehatan dan Perilaku Hidup Bersih dan Sehat Selama Pandemi Covid-19

Selain melakukan sosialisasi mengenai PHBS, anak-anak di Panti Asuhan Al-Hidayah juga didampingi dan dibimbing untuk melakukan praktik secara langsung mengenai PHBS yang sudah diajarkan. Pada tahap ini, fasilitator memberikan contoh bentuk dan cara menerapkan PHBS dalam pencegahan COVID-19, kemudian anak-anak di Panti Asuhan Al-Hidayah Mataram diminta untuk melakukan hal yang serupa sebagaimana yang diarahkan oleh fasilitator.

Dalam hal ini fasilitator memiliki peran, yaitu melakukan pendampingan dan pemberdayaan terhadap anak-anak sehingga mereka memiliki pengetahuan dan keterampilan mengenai PHBS untuk pencegahan penularan COVID-19. Selain itu, fasilitator juga memberikan pengetahuan yang relevan kepada kelompok yang menjadi sasaran pemberdayaan. Ini dilakukan agar masyarakat, dalam hal ini anak-anak yang menjadi sasaran pemberdayaan dapat mencapai tujuan 
pemberdayaan yang diinginkan (Agustin dan Supriyadi, 2017).

\section{b. Pembagian Sembako}

Sebagaimana diungkapkan di awal, bahwa anakanak terutama anak-anak di Panti Asuhan merupakan kelompok yang rentan terhadap penularan Covid-19. Untuk itu, sebagai langkah untuk meringankan beban mereka, kegiatan edukasi PHBS ini dibarengi dengan pemberian sembako untuk pemenuhan kebutuhan hidup sehari-hari anak-anak di Panti Asuhan Al-Hidayah Mataram.

Adapun jenis sembako yang dibagikan diantaranya: telur, beras, mie instan, minyak goreng, susu, gula, susu, sarden, dan sebagainya. Pembagian sembako kepada pihak penanggung jawab Panti Asuhan Al-Hidayah Kota Mataram dapat dilihat pada Gambar 4 dibawah ini:

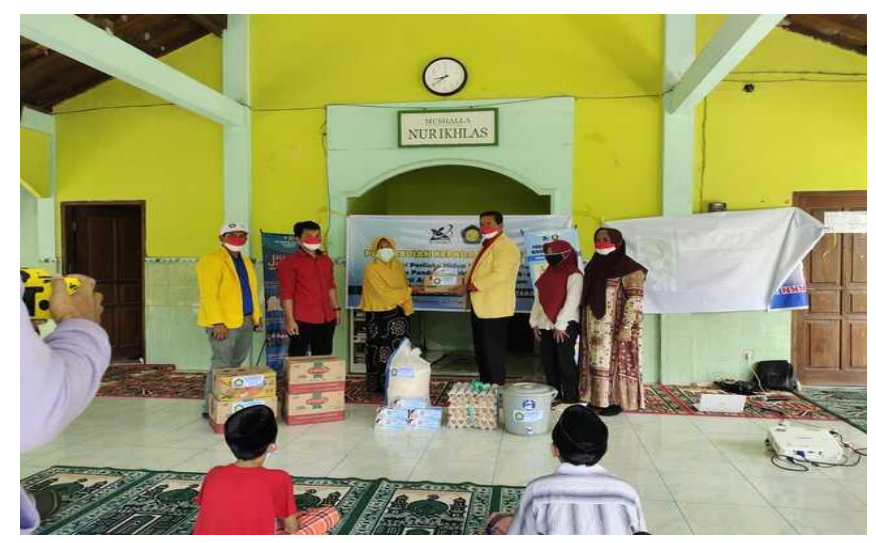

Gambar 4. Pemberian Sembako Secara Simbolis kepada Pihak Panti Asuhan Al Hidayah Kota Mataram

\section{KESIMPULAN}

Berdasarkan kegiatan pengabdian yang telah dilaksanakan di Panti Asuhan Al-Hidayah Mataram, maka dapat disimpulkan beberapa hal, yaitu: pertama, edukasi mengenai PHBS memiliki dampak pada peningkatan pengetahuan anak-anak, dimana mereka dapat mulai menerapkan perilaku hidup bersih dan sehat dalam mencegah penularan Covid-19 di dalam kehidupan mereka sehari-hari. Keberhasilan edukasi ini dapat dilihat dari tingginya antusias dan keaktifan anak-anak dalam memberi dan mejawab pertanyaan. Kedua, edukasi yang diberikan tidak hanya dalam bentuk transfer pengetahuan melalui ceramah atau sosialisasi, melainkan juga dilakukan dalam bentuk pendampingan dan bimbingan untuk mempraktikkan secara langsung apa yang sudah dipelajari. Ketiga, kegiatan edukasi dibarengi dengan kegiatan pemberian sembako untuk meringankan beban anak-anak di Panti Asuhan yang terkena dampak Covid19.

\section{UCAPAN TERIMA KASIH}

Alhamdulillah penulis panjatkan kehadirat Tuhan YME, atas terselesaikannya kegiatan pengabdian masyarakat ini. Terima kasih penulis sampaikan kepada: Sekolah Tinggi Ilmu Administrasi (STIA) Mataram, rekan-rekan Tenaga Pengajar di bawah naungan STIA Mataram, serta rekan-rekan Mahasiswa yang membantu pelaksanaan kegiatan ini. Penulis menyadari masih banyak kekurangan dalam pelaksanaan kegiatan ini. Akhir kata penulis mengharapkan semoga kegiatan ini memberikan kontribusi dan manfaat dalam pengembangan ilmu pengetahuan bagi kita semua.

\section{DAFTAR PUSTAKA}

Arsyad, A. (2013). Media Pembelajaran, edisi revisi. PT Raja Grafindo Persada: Jakarta.

Chen, Z. M., Fu, J. F., Shu, Q. (2020). Diagnosis and treatment recommendations for pediatric respiratory infection caused by the 2019 novel coronavirus. World Journal of Pediatrics.

Covid19, (2021). Peta Sebaran Covid-19. https://covid19.go.id/peta-sebaran-covid19, diakses 11 September 2021.

Durianto, Darmadi, 2011, Strategi Menaklukkan Pasar Melalui Riset Ekuitas dan Perilaku Merek, Cetakan XX, Jakarta: PT. Gramedia Pustaka Utama.

Kompas, (2021). Data Pemerintah Ungkap 12,6 Persen Anakanak Indonesia Positif Covid-19. https://nasional.kompas.com/read/2021/06/25/13094331/d ata-pemerintah-ungkap-126-persen-anak-indonesia-positifcovid-19? page=all, diakses September 2021.

Huang C, Wang Y, Li X. (2020). Clinical features of patients infected with 2019 novel coronavirus in Wuhan, China. Lancet. 395: 497-506.

Razi F., Yulianty V., Amani, S A., Fauzia J H. (2020). Bunga Rampai COVID-19: Buku Kesehatan Mandiri untuk Sahabat. PD Prokami: Depok. 
Singhal, T. (2020 ). A Review of Coronavirus Disease -2019 (COVID -19). The Indian Journal of Pediatrics, 87(4): 281 -286 .

World Health Organization. (2021). WHO Coronavirus (COVID-19) Dashboard. https://covid19.who.int/, diakses 11 September 2021.

Zimmermann, P., dan Curtis, N. (2020). Coronavirus Infections in Children Including COVID -19. The Pediatric Infectious Disease Journal. 39(5): 355 -368. 